\title{
Variation in litter mass and its turnover in Tarai Sal forest and Hill Sal forest of eastern Nepal
}

\author{
Krishna Prasad Bhattarai ${ }^{\mathbf{1}}$ and Tej Narayan Mandal $^{\mathbf{2}}$ \\ ${ }^{1}$ Department of Botany, Mechi Multiple Campus, T.U., Bhadrapur, Nepal \\ ${ }^{2}$ Department of Botany, Post Graduate Campus, T.U., Biratnagar, Nepal \\ *E-mail: krishnaprbhattarai@gmail.com; tnmandal@gmail.com
}

\begin{abstract}
Litter on the forest floor is an important source of nutrient cycling which helps to improve the soil fertility in forest ecosystem. Comparative study was conducted to investigate the amount of annual litter mass, seasonal variation and its turnover in Tarai Sal forest (TSF) and Hill Sal forest (HSF) of eastern Nepal. Litter mass was collected in each season from $1 \mathrm{~m}$ $\times 1 \mathrm{~m}$ quadrat placed randomly on the forest floor. The total annual litter mass in TSF $\left(6.73 \mathrm{Mg} \mathrm{ha}^{-1}\right)$ was significantly $(\mathrm{p}<0.001)$ higher than in HSF $\left(5.63 \mathrm{Mg} \mathrm{ha}^{-1}\right)$. The seasonal pattern of litter mass was higher in summer $\left(9.04 \mathrm{Mg} \mathrm{ha}^{-1}\right.$ and $7.44 \mathrm{Mg} \mathrm{ha}^{-1}$ ) followed by rainy $\left(6.29 \mathrm{Mg} \mathrm{ha}^{-1}\right.$ and 5.11 $\mathrm{Mg} \mathrm{ha}^{-1}$ ) and winter season (4.9 Mg ha-1 and 4.35 Mg ha-1) in TSF and HSF, respectively. The turnover rate for litter mass on the forest floor was higher $(79 \%)$ in TSF than HSF (70\%). However, turnover time was higher in HSF than TSF. Standing state nutrient in the litter layer was higher in TSF (56.21 kg N ha' $\mathrm{yr}^{-1}, 6.19 \mathrm{~kg} \mathrm{P} \mathrm{ha}^{-1} \mathrm{yr}^{-1}$ and $17.15 \mathrm{~kg} \mathrm{~K} \mathrm{ha}^{-1}$ $\mathrm{yr}^{-1}$ ) than HSF (45.16 kg N ha-1 $\mathrm{yr}^{-1}, 4.7 \mathrm{~kg} \mathrm{P}^{-1} \mathrm{yr}^{-1}$ and $14.19 \mathrm{~kg} \mathrm{~K} \mathrm{ha}^{-1}$ $\left.\mathrm{yr}^{-1}\right)$. The difference in litter mass between these two forests may be due to differences in micro climate, soil properties and species composition.
\end{abstract}

Key words: Sal forest, Nutrients, Soil fertility, Forest ecosystem.

\section{Introduction}

Litter mass compilation is a standard non-destructive method for assessing the productivity and turnover of organic matter in the forest. It is one of the most important pathways through which nutrients are returned to the forest floor (Bellingham et al., 2013) and affects the moisture status, run-off pattern, and nutritional characters of the land (Garkoti \& Singh, 1995). Determining the dynamics of litterfall and available litter nutrient stocks over time is a fundamental aspect of functioning of terrestrial ecosystems (Maritus et al., 2004). Both the biomass of the litter and its chemical content are needed to quantify the annual return of elements and organic matter to the soil (Hansen et al., 2009). Litterfall dynamics in the natural forest ecosystems is strongly influenced by density, basal area, age structure (Stonhlgren, 1988), seasons (Sundharapandian \& Swamy, 1999) and altitude (Garkoti \& Singh, 1995). The altitudinal variation influences the microclimate as well as the activities of microorganisms which retard or accelerate turnover of leaf litter (Vitousek et al., 1994).

The present study provides a basis for comparison of litter mass and its turnover in the Sal forests which are located at different altitudes in eastern Nepal. In Nepal comparative study on litter mass and its turnover in forests located in different altitude is limited. So, the purpose of this study was to focus on the amount of litter mass on Tarai Sal forest of Jalthal and Hill Sal forest of Kiteni. The study was conducted with the following specific 
objectives: (i) to assess the variation in the amount of litter mass due to variation in altitude (ii) to examine the seasonality, turnover and standing state nutrient $(\mathrm{N}, \mathrm{P}, \mathrm{K})$ in litter mass.

\section{Materials and Methods \\ Study area}

The present study was carried out in the Sal forests located in Tarai and Hill regions of eastern Nepal. Sal forest of Tarai region, addressed as Tarai Sal forest, is located at Jalthal VDC near Kechana (extreme lowland of Nepal) of Jhapa district in eastern Nepal. The forest floor is uneven and altitudinal variation ranges from 62 to $129 \mathrm{~m}$ msl. TSF is situated in between $87^{\circ} 55^{\prime}$ and $88^{\circ} 03^{\prime} \mathrm{E}$ and $26^{\circ} 27^{\prime}$ and $26^{\circ} 32^{\prime} \mathrm{N}$ (Fig. 1). Sal forest of Hill region, addressed as Hill Sal forest, is located at Kiteni of Kolbung VDC, Ilam district. This forest lies at the sub Himalayan tract (Shiwaliks) where the altitude ranges from 500 to $850 \mathrm{~m}$ msl. HSF is situated in between long. $88^{\circ} 02^{\prime}$ and $88^{\circ} 04^{\prime}$ E and lat. $26^{\circ} 44^{\prime}$ and $26^{\circ} 47^{\prime} \mathrm{N}$.

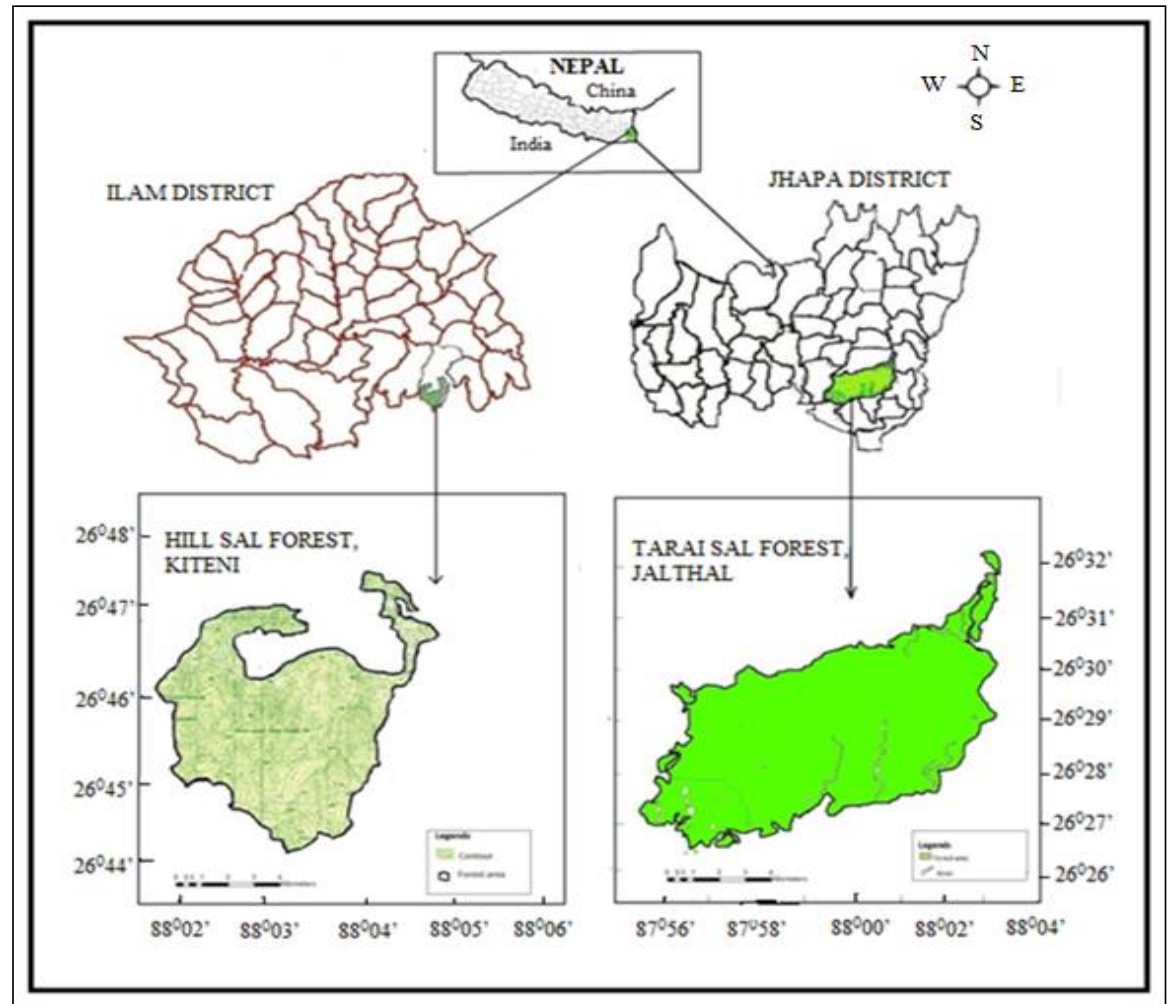

Figure 1. Location of study area of Hill Sal forest lies at Kiteni, Ilam district and Tarai Sal forest lies at Jalthal, Jhapa district in eastern Nepal.

The climate of the study area is tropical monsoon type. Based on the data pertaining to the period 2001- 2014, the mean monthly minimum temperature of TSF ranged from $10^{\circ} \mathrm{C}$ to $24^{\circ} \mathrm{C}$ and maximum temperature ranged from $23.9^{\circ} \mathrm{C}$ to $33.4^{\circ} \mathrm{C}$. Likewise, the mean monthly minimum temperature of $\mathrm{HSF}$ ranged between $9.4^{\circ} \mathrm{C}$ and $19.9^{\circ} \mathrm{C}$ and maximum temperature between $16.4^{\circ} \mathrm{C}$ and $25.9^{\circ} \mathrm{C}$. The average annual rainfall of TSF was 2130.4 $\mathrm{mm}$ and for HSF was $1776.07 \mathrm{~mm}$. Both TSF and HSF are dominated by Shorea robusta Gaertn. Soil of TSF and HSF is sandy loam type. 


\section{Litter mass}

Litter mass accumulated at each site was collected once every season from the thirty litter trap $(1 \mathrm{~m} \times 1 \mathrm{~m})$ placed randomly on the forest floor. The collected litter mass was brought to laboratory and separated as: (a) fresh leaf litter (b) non-leaf litter and (c) partially decayed litter. The samples were oven dried at $80^{\circ} \mathrm{C}$ to a constant weight and mean value of each component was calculated.

\section{Litter mass chemical analysis}

Litter mass samples were pooled together separately in proportion to their volume to represent annual samples for each forest site. The oven dried samples of each litter mass component was ground separately and passed through $1 \mathrm{~mm}$ mesh screen. Three separate samples of various components were analyzed for each site. The total nitrogen concentration was determined by micro-Kjeldahl method (Peach \& Tracey, 1956). Using method developed by Allen et al. (1974), $200 \mathrm{mg}$ oven dried plant material was digested in $7 \mathrm{ml}$ triacid mixture (5:1:1, nitric acid: sulphuric acid: perchloric acid), cooled and transferred on hot plate till the material became pink colored and diluted to $100 \mathrm{ml}$ by using triple distilled water. Using $5 \mathrm{ml}$ aliquot, $\mathrm{NH}_{4}$ molybdate and $\mathrm{SnCl}_{2}$, the total $\mathrm{P}$ was determined colorimetrically by blue color in a spectrophotometer. Potassium was determined by atomic absorption spectrophotometer. The turnover rate $(k)$ for each element on the forest floor was calculated as $k=\mathrm{A} /(\mathrm{A}+\mathrm{F})$, (Jenny et al., 1949), where $A$ is the amount of nutrient added to the forest floor annually by litterfall and $F$ is the nutrient content of the lowest value of standing crop of litter in the annual cycle. Turnover time (t) is the reciprocal of the turnover rate $(k)$ and is expressed as $t=1 / k$.

\section{Statistical analysis}

Two ways ANOVA was used to test the level of significance in litter mass due to stand type and seasons to determine sitewise and seasonal differences by using an IBM SPSS Statistics (v. 20) software.

\section{Results \\ Litter mass}

Litter mass accumulated on forest floor was higher in TSF (6.73 $\mathrm{Mg} \mathrm{ha}^{-1}$ ) than HSF (5.63 $\mathrm{Mg} \mathrm{ha} \mathrm{h}^{-1}$ ). Contribution of leaf litter was $36 \%$ and 35\%, non leaf litter was $27 \%$ and $23 \%$ and partially decayed litter was $37 \%$ and $42 \%$ on annual litter mass in TSF and HSF, respectively (Table 1).

Table 1. Forest floor litter mass $\left(\mathrm{Mg} \mathrm{ha}^{-1} \pm \mathrm{SE}\right.$, average of three seasons) and turnover of litter (rate and time) of Tarai Sal forest and Hill Sal forest

\begin{tabular}{cllll}
\hline Litter mass components & Tarai Sal forest & \% of total & Hill Sal forest & \% of total \\
\hline Leaf litter & $2.43 \pm 0.01$ & 36 & $1.97 \pm 0.04$ & 35 \\
Non leaf litter & $1.84 \pm 0.01$ & 27 & $1.29 \pm 0.03$ & 23 \\
Partially decayed & $2.46 \pm 0.03$ & 37 & $2.36 \pm 0.03$ & 42 \\
\hline Total & $6.73 \pm 0.05$ & & $5.63 \pm 0.11$ & \\
\hline Turnover rate $\left(\mathrm{K}, \mathrm{yr}^{-1}\right)$ & 0.79 & & 0.70 & \\
\hline Turn over time $\left(\mathrm{t}, \mathrm{yr}^{-1}\right)$ & 1.26 & & 1.42 & \\
\hline
\end{tabular}

Amount of litter mass present on forest floor varied with season on both forest stands. Leaf litter mass was higher in summer season, value gradually decreased in rainy and winter 
season. However, the value of partially decayed litter mass was lower during summer season middle value at winter season and higher value at rainy season. Partially decayed litter mass was higher in HSF during winter season only (Fig. 2). The turnover rate for litter mass on the forest floor was higher (79\%) in TSF than HSF (70\%). However turn over time was higher in HSF than TSF.

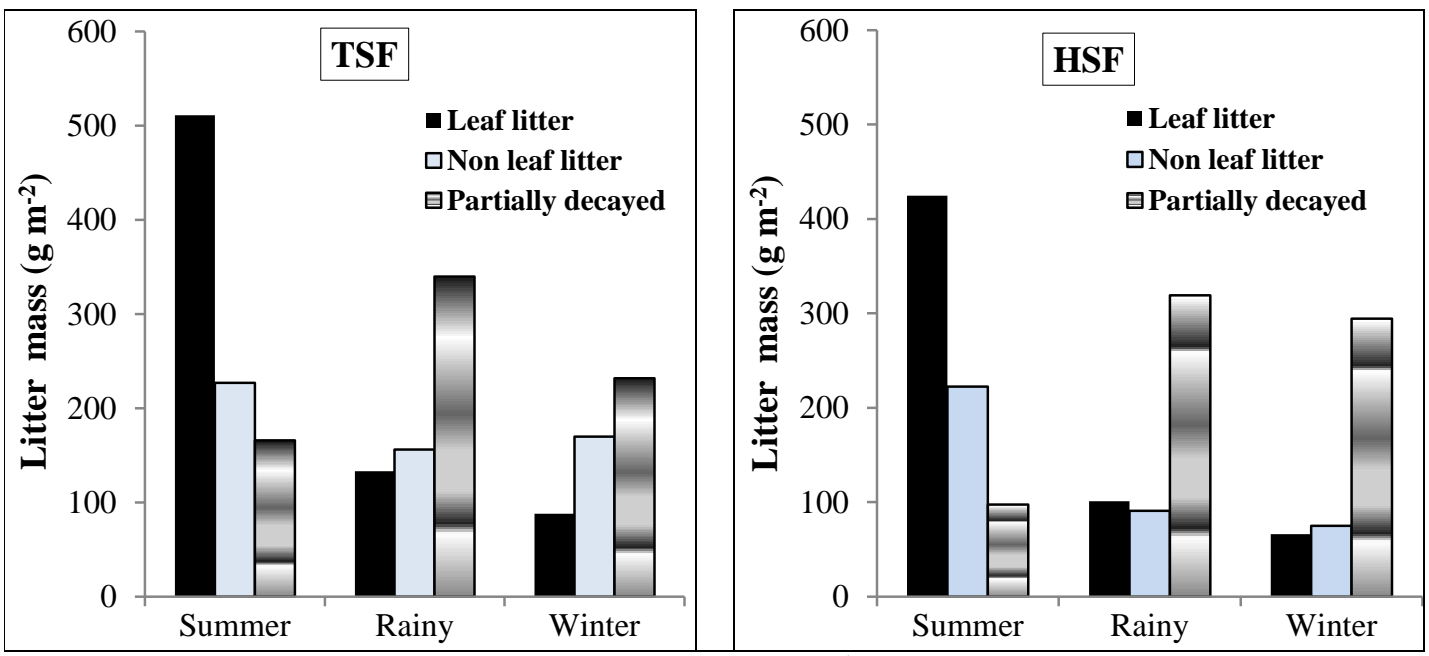

Figure 2. Seasonal variation in forest litter mass $\left(\mathrm{Mg} \mathrm{ha}^{-1} \pm \mathrm{SE}\right)$ at Tarai Sal forest and Hill Sal forest; seasonal representations are as: Summer (March-June), Rainy (July- October) and Winter (November-February)

\section{Nutrients in litter mass and its turnover}

Standing state nutrient in litter mass was higher in TSF $\left(56.21 \mathrm{~kg} \mathrm{~N} \mathrm{ha}^{-1}, 6.19 \mathrm{~kg} \mathrm{P} \mathrm{ha}^{-1}\right.$ and $17.15 \mathrm{~kg} \mathrm{~K} \mathrm{ha}^{-1}$ ) than HSF (45.16 $\mathrm{kg} \mathrm{N} \mathrm{ha}^{-1}, 4.7 \mathrm{~kg} \mathrm{P} \mathrm{ha}^{-1}$ and $14.9 \mathrm{~kg} \mathrm{~K} \mathrm{ha}^{-1}$ ). The percentage value of standing state nutrient of partly decayed litter was higher than other components of litter mass in both forests. However, this value was higher in HSF than TSF (Table 2). The turnover rate for different litter nutrients (N, P and $\mathrm{K}$ ) on the forest floor was higher $(0.59,0.58$ and 0.61$)$ in TSF than $\operatorname{HSF}(0.54,0.55$ and 0.58$)$. However, the turnover time was reciprocal of turnover rate of litter floor mass. The turnover time of litter nutrients was higher in HSF than TSF (Table 3).

Table 2. Standing state nutrients $\left(\mathrm{kg} \mathrm{ha}^{-1} \mathrm{yr}^{-1} \pm \mathrm{SE}\right)$ in litter layer in Tarai Sal forest and Hill Sal forest

\begin{tabular}{lccc}
\hline \multirow{2}{*}{ Forests/Components } & \multicolumn{3}{c}{ Nutrients } \\
\cline { 2 - 4 } & $\mathbf{N}$ & $\mathbf{P}$ & $\mathbf{K}$ \\
\hline Tarai Sal forest & $56.21 \pm 0.23$ & $6.19 \pm 0.03$ & $17.15 \pm 0.54$ \\
Fresh leaf litter (\%) & 37 & 38 & 48 \\
Partly decayed litter (\%) & 42 & 45 & 35 \\
Non leaf litter (\%) & 21 & 17 & 17 \\
\hline Hill Sal forest & $45.16 \pm 0.26$ & $4.7 \pm 0.06$ & $14.19 \pm 0.28$ \\
Leaf litter (\%) & 35 & 35 & 46 \\
Partly decayed litter (\%) & 48 & 51 & 41 \\
Non leaf litter (\%) & 17 & 14 & 13 \\
\hline
\end{tabular}


Table 3. Turnover rate $(\mathrm{k})$ and turnover time $(\mathrm{t})$ of litter nutrients on forest floor in Tarai Sal forest and Hill Sal forest

\begin{tabular}{lccc}
\hline \multirow{2}{*}{ Forests } & \multicolumn{3}{c}{ Nutrients } \\
\cline { 2 - 4 } & $\mathbf{N}$ & $\mathbf{P}$ & $\mathbf{K}$ \\
\hline Turnover rate & 0.59 & 0.58 & 0.61 \\
Tarai Sal forest & 0.54 & 0.55 & 0.58 \\
Hill Sal forest & & & \\
\hline Turnover time & 1.69 & 1.72 & 1.63 \\
\hline Tarai Sal forest & 1.85 & 1.81 & 1.72 \\
\hline Hill Sal forest &
\end{tabular}

\section{Discussion}

Litter accumulation in moist forest is mainly influenced by favorable microclimate such as temperature, rainfall and differences in species composition (Yang et al., 2004). Hill Sal forest showed lower value of litter mass on the forest floor due to lower litter production as it is located on high altitude. Forest floor litter mass of the present study was similar with the results obtained by Yang (2005) in Wanmulin Nature Reserve, China (6.71 $\left.\mathrm{Mg} \mathrm{ha}^{-1}\right)$, Mandal (1999) in Plateau Sal forest, Nepal (5.6 Mg ha-1) while it was higher than the value reported by Toriyama et al. (2015) in the Cambodian dry tropical deciduous forest (1.45 $\left.\mathrm{Mg} \mathrm{ha}^{-1}\right)$ and evergreen forest $\left(2.16 \mathrm{Mg} \mathrm{ha}^{-1}\right)$.

Turnover rate of litter layer on the forest floor indicate the percentage replacement of litter mass in each year. It was higher in TSF due to high temperature and soil moisture and it decreased in HSF due to high altitude, lower temperature and low soil moisture. Same trend in turnover was reported by Garkoti \& Singh (1995) in the forests of Central Himalaya. Lugo et al. (1978) reported a lower turnover rate (0.34) for sub tropical dry forest at Puerto Rico, while the turnover rate of three tropical Australian rain forests was as high as 1.4- 2.2 (Spain, 1984). Turnover time which is reciprocal of turnover rate was longer in HSF, reflects slower turnover rate due to variation in altitude and climatic conditions. It is comparable to the range reported for several tropical and sub tropical evergreen and deciduous forests by Vogt et al. (1986). Similarly, the turnover rate for different litter nutrients $(\mathrm{N}, \mathrm{P}$ and $\mathrm{K})$ on the forest floor was higher in TSF due to rapid mass loss.

Standing state nutrient in different components of litter mass was higher in TSF than HSF. Nutrient stock in the forest floor depends upon quantity of litter mass. Moreover, it may also depend upon nutrient concentration of litter which depend upon sites and characteristics of the species involved (Yang et al., 2005). The value of nutrients was higher in partly decayed litter than other components of litter mass in both forests. This may be due to immobilization of nutrients by microorganisms. The nutrient contribution to the forest floor through the litter mass in the present study was comparable to that reported by Garkoti \& Singh (1995) in forest of central Himalaya, India and Mandal (1999) in Plateau Sal forest, Nepal. Similarly, the turnover rate for different litter nutrients (N, P and $\mathrm{K}$ ) on the forest floor was higher in TSF than HSF but the turnover time of litter nutrients was higher in HSF. The turnover time of $\mathrm{N}$ and $\mathrm{P}$ was higher than $\mathrm{K}$ which may be due to release of $\mathrm{K}$ from the initial phase without immobilization.

\section{Acknowledgements}

The authors are grateful to the Head, Department of Botany and to the Campus Chief of Post Graduate Campus, T.U., Biratnagar, Nepal for providing laboratory and library 
facilities. The first author is grateful to the Institute of Science and Technology Tribhuvan University Kathmandu for Ph.D. study leave and to the University Grants Commission, Nepal for the research fellowship.

\section{Reference}

Allen, S.E., H.M. Grimshaw, J.A. Parkinson \& C. Quarmby 1974. Chemical Analysis of Ecological Materials. Blackwell Scientific Publication, Oxford.

Bellingham, P.J., C.W. Morse, R.P. Buxton, K.I. Bonner, N.W.H. Mason \& D.A.Wardle. 2013. Litterfall, nutrient concentrations and decomposability of litter in a New Zealand temperate montane rain forest. New Zealand Journal of Ecology 37(2): 162-171.

Garkoti, S.C. \& S.E. Singh. 1995. Forest floor mass, litterfall and nutrient return in Central Himalayan high altitude forests. Vegetatio 120: 33-48.

Hansen, K., L. Vesterdal, I.K. Schmidt, P. Gundersen, L. Sevel, A. Bastrup-Birk, L. B. Pedersen, J. Bille-Hansen. 2009. Litterfall and nutrient return in five tree species in a common garden experiment. Forest Ecology and Management 257: 2133- 2144.

Jenny, H., S.P. Gessel \& F.T. Bingham. 1949. Comparative study of decomposition rates of organic matter in temperate and tropical regions. Soil Science 68: 419-432.

Lugo, A.E., J.A. Gonzalez-Libboy, B. Cintron \& K. Dugger. 1978. Structure, productivity, and transpiration of a subtropical dry forest in Puerto Rico. Biotropica 10: 278- 291.

Mandal, T.N. 1999. Ecological Analysis of Recovery of Landslide Damaged Sal Forest Ecosystem in Nepal Himalaya. Ph. D. Thesis, Banarus Hindu University, Varanasi, India.

Martius, C., H. Höfer, M.A.V. Garcia, J. Römbke \& W. Hanagarth. 2004. Litter fall, litter stocks and decomposition rates in rainforest and agroforestry sites in central Amazonia. Nutrient Cycling in Agroecosystems 68: 137-154.

Peach, K. \& M.V. Tracey. 1956. Modern Methods of Plant Analysis. Vol. 1. Springer- Verlag, Berlin.

Spain, A.V. 1984. Litterfall and the standing crop of litter in three tropical Australian rainforests. Journal of Ecology 12: 947- 961.

Stonhlgren, T.J. 1988. Litter dynamics in two Sierran mixed conifer forest. I. Litterfall and decomposition rates. Canadian Journal of Forest Resources 18: 1127-1135.

Sundarapandian, S.M. \& P.S. Swamy. 1999. Litter production and leaf-litter decomposition of selected tree species in tropical forests at Kodayar in the Western Ghats, India. Forest Ecology and Management 123 (2-3): 231-244.

Toriyama, J., M. Hak, A. Imaya, K. Hirai \& Y. Kiyono. 2015. Effects of forest type and environmental factors on the soil organic carbon pool and its density fractions in a seasonally dry tropical forest. Forest Ecology and Management 335: 147-155.

Vitousek, P.M. 1984. Litterfall, nutrient cycling, and nutrient limitation in tropical forests. Ecology 65: 285-298.

Vogt, K.A., C.C. Grier \& D.J. Vogt. 1986. Production, turnover and nutrient dynamics of above- and belowground detritus of world forests. Advances in Ecological Research 15: 303-377.

Yang, Y.S., J.F. Guo, G.S. Chen, J.S. Xie, R. Gao, Z. Li, \& Z. Jin 2005. Litter production, seasonal pattern and nutrient return in seven natural forests compared with a plantation in southern China. Forestry, 78(4): 403-415.

Yang, Y.S., J.F. Guo, G.S. Chen, R.Y. Lin, L.P. Cai \& P. Lin. 2004. Litterfall, nutrient return and leaf litter decomposition in four plantations compared with a natural forest in subtropical China. Ann. For. Sci. 61: 465 - 476. 